\title{
Environmental Energy Sustainability at Universities
}

\author{
Francisco G. Montoya ${ }^{1}\left[\right.$ and Alberto-Jesus Perea-Moreno ${ }^{2, *} * \mathbb{C}$ \\ 1 Department of Engineering, University of Almeria, ceiA3, 04120 Almeria, Spain; pagilm@ual.es \\ 2 Department of Applied Physics, Radiology and Physical Medicine, University of Cordoba, \\ Campus de Rabanales, 14071 Córdoba, Spain \\ * Correspondence: aperea@uco.es; Tel.: +34-957-212633
}

Received: 2 November 2020; Accepted: 4 November 2020; Published: 5 November 2020

\begin{abstract}
The use of renewable energies and energy saving and efficiency are needs of global society and universities. Universities have a large responsibility and social impact, as they are an example and engine of social change. Universities, in the European context, must be at the forefront of sustainability progress, seeking to be at the same level, and preferably higher than the rest of society, seeking the goal of $20 \%$ in renewable energy for 2020 and, in the longer term, greater energy efficiency based on a diverse use of renewable energy and studying the feasibility of other energy processes (cogeneration, trigeneration, etc.). The application of renewable energies and efficiency allow universities to make significant savings in their costs and contribute to sustainable development and the fight against climate change. Actions on these aspects in addition to the objective of saving should seek to promote research and form an example for the university community. This Special Issue aims to advance the contribution of energy saving and the use of renewable energies in order to achieve more sustainable universities.
\end{abstract}

Keywords: energy saving; renewable energy; universities; zero-energy buildings; energy efficiency; sustainability; bioclimatic architecture; sustainable transport; photovoltaic; energy saving in laboratories; energy saving in data processing centres

\section{Introduction}

Efficient energy consumption has now become one of the most important points on which society must raise awareness and work on it, because it is today, more than ever, when natural resources are scarcer and scientists are showing more evidence of climate change. Energy consumption is one of the main sources of environmental impact at the University, and also represents a significant economic expense. Likewise, from the environmental point of view, it is worth noting that through the energy savings, we will be contributing to a good use of energy and, in turn, we will be providing solutions that minimize the impact or energy footprint on society. In this sense, a lower use of resources and the promotion of renewable energies will result in an important contribution to reduce the evolution towards a negative climate change.

This Special Issue aims to advance the contribution of energy saving and the use of renewable energies in order to achieve more sustainable universities. This Special Issue seeks contributions spanning a broad range of topics related but not limited to:

- Solar energy

- The use of rooftops for energy generation

- Energy conversion from urban biomass or residues

- Energy management for sewage water

- Bioclimatic architecture and green buildings

- Wind energy cogeneration 
- Public and private urban energy saving

- Policy for urban energy saving

- Electric meters

- Zero-energy buildings

\section{Publication Statistics}

The publication statistics of the call of papers for this Special Issue, regarding the articles published or rejected with respect to the total number of articles submitted, were:

- $\quad 14$ articles submitted (100\%)

- $\quad 4$ articles rejected $(28.6 \%)$

- 10 articles published $(71.4 \%)$

The regional distribution of authors by countries for the published articles is presented in Table 1, in which it is possible to observe 24 authors from three countries. Note that it is usual for an item to be signed by more than one author and for authors to collaborate with others from different countries.

Table 1. Authors' countries.

\begin{tabular}{cc}
\hline Country & Authors \\
\hline Spain & 12 \\
Mexico & 9 \\
Colombia & 3 \\
\hline Total & 24 \\
\hline
\end{tabular}

\section{First Affiliation and Country of the Special Issue Authors}

Table 2 shows the affiliations of the authors who have participated in this Special Issue.

Table 2. Authors' affiliations of this Special Issue.

\begin{tabular}{|c|c|c|c|}
\hline Author & First Affiliation & Country & Reference \\
\hline Garrido-Yserte, R. & University of Alcalá & Spain & [1] \\
\hline Gallo-Rivera, M.-T. & University of Alcalá & Spain & [1] \\
\hline Perea-Moreno, M.-A. & Universidad Internacional de La Rioja (UNIR) & Spain & {$[2-4]$} \\
\hline Hernandez-Escobedo, Q. & Universidad Nacional Autónoma de México & Mexico & [2-5] \\
\hline Rueda-Martinez, F. & Universidad Nacional Autónoma de México & Mexico & [2] \\
\hline Perea-Moreno, A.-J. & University of Cordoba & Spain & {$[2-4]$} \\
\hline Ramirez-Jimenez, A. & University of Almeria & Spain & [3] \\
\hline Dorador-Gonzalez, J.M. & Universidad Nacional Autónoma de México & Mexico & [3] \\
\hline Grisales-Noreña, L.F. & Instituto Tecnológico Metropolitano & Colombia & [5] \\
\hline Ramos-Paja, C. & Universidad Nacional de Colombia & Colombia & [5] \\
\hline Gonzalez-Montoya, D. & Instituto Tecnológico Metropolitano & Colombia & [5] \\
\hline Alcalá, G. & Universidad Veracruzana & Mexico & [5] \\
\hline Manzano-Agugliaro, F. & University of Almeria & Spain & {$[4,6-8]$} \\
\hline Chihib, M. & University of Almeria & Spain & {$[6,7]$} \\
\hline Salmerón-Manzano, E. & Universidad Internacional de La Rioja (UNIR) & Spain & [6-8] \\
\hline Novas, $\mathrm{N}$. & University of Almeria & Spain & [7] \\
\hline Leon, I. & University of the Basque Country UPV/EHU & Spain & [9] \\
\hline Oregi, $\mathrm{X}$ & University of the Basque Country UPV/EHU & Spain & [9] \\
\hline Marieta, C. & University of the Basque Country UPV/EHU & Spain & [9] \\
\hline Chavero-Navarrete, E. & Universidad Autónoma de Querétaro & Mexico & [10] \\
\hline Trejo-Perea, M. & Universidad Autónoma de Querétaro & Mexico & [10] \\
\hline Jáuregui-Correa, J.-C. & Universidad Autónoma de Querétaro & Mexico & [10] \\
\hline Carrillo-Serrano, R.-V. & Universidad Autónoma de Querétaro & Mexico & [10] \\
\hline Rios-Moreno, J.-G. & Universidad Autónoma de Querétaro & Mexico & [10] \\
\hline
\end{tabular}




\section{Topics of Environmental Energy Sustainability at Universities}

The research carried out by the different authors is classified according to the topics of the Special Issue in Table 3. It was noted that one "Environmental Energy Sustainability at Universities" topic dominated the rest: "Sustainability".

Table 3. Topics of Environmental Energy Sustainability at Universities.

\begin{tabular}{ccc}
\hline Topics & Number of Manuscripts & Reference \\
\hline Energy efficiency & 2 & {$[1,6]$} \\
Energy conversion from urban biomass or residues & 2 & {$[2,4]$} \\
Solar energy & 2 & {$[3,5]$} \\
Sustainability & 3 & {$[7-9]$} \\
Wind energy & 1 & {$[10]$} \\
\hline
\end{tabular}

Author Contributions: The authors all made equal contributions to this article. All authors have read and agreed to the published version of the manuscript.

Funding: This research received no external funding.

Conflicts of Interest: The authors declare no conflict of interest.

\section{References}

1. Garrido-Yserte, R.; Gallo-Rivera, M.-T. The potential role of stakeholders in the energy efficiency of higher education institutions. Sustainability 2020, 12, 8908. [CrossRef]

2. Perea-Moreno, M.-A.; Hernandez-Escobedo, Q.; Rueda-Martinez, F.; Perea-Moreno, A.-J. Zapote seed (Pouteria mammosa L.) valorization for thermal energy generation in tropical climates. Sustainability 2020, 12, 4284. [CrossRef]

3. Hernandez-Escobedo, Q.; Ramirez-Jimenez, A.; Dorador-Gonzalez, J.M.; Perea-Moreno, M.-A.; Perea-Moreno, A.-J. sustainable solar energy in mexican universities. case study: The National School of Higher Studies Juriquilla (UNAM). Sustainability 2020, 12, 3123. [CrossRef]

4. Perea-Moreno, M.-A.; Manzano-Agugliaro, F.; Hernandez-Escobedo, Q.; Perea-Moreno, A.-J. Sustainable thermal energy generation at universities by using loquat seeds as biofuel. Sustainability 2020, 12, 2093. [CrossRef]

5. Grisales-Noreña, L.F.; Ramos-Paja, C.A.; Gonzalez-Montoya, D.; Alcalá, G.; Hernandez-Escobedo, Q. Energy management in PV based microgrids designed for the Universidad Nacional de Colombia. Sustainability 2020, 12, 1219. [CrossRef]

6. Chihib, M.; Salmerón-Manzano, E.; Manzano-Agugliaro, F. Benchmarking energy use at University of Almeria (Spain). Sustainability 2020, 12, 1336. [CrossRef]

7. Chihib, M.; Salmerón-Manzano, E.; Novas, N.; Manzano-Agugliaro, F. Bibliometric maps of BIM and BIM in universities: A comparative analysis. Sustainability 2019, 11, 4398. [CrossRef]

8. Salmerón-Manzano, E.; Manzano-Agugliaro, F. The role of smart contracts in sustainability: Worldwide research trends. Sustainability 2019, 11, 3049. [CrossRef]

9. Leon, I.; Oregi, X.; Marieta, C. Contribution of university to environmental energy sustainability in the city. Sustainability 2020, 12, 774. [CrossRef]

10. Chavero-Navarrete, E.; Trejo-Perea, M.; Jáuregui-Correa, J.-C.; Carrillo-Serrano, R.-V.; Rios-Moreno, J.-G. Pitch angle optimization by intelligent adjusting the gains of a pi controller for small wind turbines in areas with drastic wind speed changes. Sustainability 2019, 11, 6670. [CrossRef]

Publisher's Note: MDPI stays neutral with regard to jurisdictional claims in published maps and institutional affiliations.

(C) 2020 by the authors. Licensee MDPI, Basel, Switzerland. This article is an open access article distributed under the terms and conditions of the Creative Commons Attribution (CC BY) license (http://creativecommons.org/licenses/by/4.0/). 